\title{
O ENSINO DE LITERATURA E A INTERCONEXÃO ENTRE REPRESENTAÇÃO LITERÁRIA E HISTÓRIA
}

\section{Belmira Magalhães ${ }^{(*)}$}

Resumo: Este artigo pretende instigar o debate sobre o ensino de literatura nas universidades, partindo de uma concepção que considera a literatura como uma forma de representação da realidade social. Para este momento, ancoramo-nos em teóricos da literatura como Lukács, Bakhtin, Williams e Candido, que enfatizam, cada um de modo particular, a interdependência entre literatura e história, e na Teoria do Discurso, que considera o fazer literário como uma práxis discursiva.Realizamos uma análise do poema Manhã, de Otávio Cabral, procurando mostrar uma possibilidade de análise que tende a despertar o interesse do estudante, por inseri-lo como persona da história, em todos os sentidos.

Palavras-chave: Literatura, Análise do discurso, Crítica Literária e Ensino

Um ponto de vista

Neste artigo propomos uma leitura do texto literário com o sentido de instigar o debate sobre o ensino de literatura. Para tanto, faremos uma leitura do poema Manhã, de Otávio Cabral, procurando demonstrar a necessidade de análises que levem em consideração a dialogia inerente ao texto literário, que necessariamente passa pela fricção entre representação literária e representação social, considerada como uma práxis ${ }^{1}$ discursiva.

Para tal tarefa estamos nos ancorando em Bakhtin, com o conceito de dialogia, e em Pêcheux, através do conceito de interdiscursividade, os quais pressupõem uma relação dialética entre a

(*) Professora/pesquisadora do Programa de Pós-graduação em Letras e Lingüística da Ufal, nas áreas de Literatura e sociedade e Análise do discurso.

1 A noção de práxis implica sempre a compreensão de uma ação da subjetividade, que realiza uma intervenção (teórica, estética, política etc.) sobre a realidade. 
subjetividade e a objetividade constitutiva de toda práxis discursiva, inclusive a literária, estabelecendo o lugar do outro (histórico) no discurso; em Candido, na ressignificação permeante entre as relações sociais e a representação literária, principalmente através do conceito de redução estrutural; e em Lukács, que, através do conceito de particularidade estética, afirma a função social da arte.

Cada vez mais as disciplinas que tratam do específico do discurso literário vêm perdendo espaço nas escolas de ensino médio, nos concursos vestibulares e no percentual de alunos que optam por essa concentração nos cursos de Letras, e, o que é mais sério, cada vez mais se reduz o gosto dos alunos pela literatura. Como se não bastasse, há casos em que os alunos de graduação não lêem sequer os clássicos brasileircs e, muito menos, os estrangeiros, mas recebem um diploma que os tornará aptos ao ensino de literatura no nível médio. Ao se declararem avessos à leitura, como irão transmitir esse gosto a seus alunos? Cria-se um círculo vicioso que necessita ser rompido.

Nossa primeira constatação é a de que a literatura tem sido usada como pretexto para o ensino da gramática, servindo, na maioria das vezes, como exemplo de desvio às regras, ou transgressão às normas gramaticais, perdendo, assim, o texto literário sua relação com a vida, deixando de ser uma reflexão sobre a realidade, que poderia encantar os alunos, para ser apenas expressão de forma lingüística.

Outra constatação, principalmente no que se refere à história da literatura, é a da prisão que se estabelece em relação aos estilos de épocas literárias, ensinando-se ao aluno apenas as características de cada uma, servindo o texto literário apenas como ilustração às classificações ${ }^{2}$. Os alunos perdem, dessa forma, a noção de que as escolas são uma decorrência da criatividade dos escritores em cada época histórica, em uma relação com o momento histórico-social.

As determinações da realidade são o pressuposto da arte, cabendo à análise literária esclarecer como um sujeito histórico reflete uma realidade também histórica, porque obra de homens e mulheres reais (MAGALHÃES, 2002,134).

2 Os alunos ficam sujeitos aos recortes que os livros de história da literatura fazem para caracterizar as escolas, acabando por não lerem as obras completas. 
Os estudos contemporâneos sobre a língua, em especial a Análise do discurso, têm demonstrado que a transgressão, o equívoco são constitutivos da linguagem, não sendo portanto propriedades de certos lugares de enunciação, mas fazem parte da relação entre um sujeito do inconsciente, interpelado pela ideologia, com a língua.

No entanto, essa realidade passa efetivamente pelo crivo de uma subjetividade que terá de processá-la a partir de seu lugar social e de suas concepções sobre o conteúdo que pretende refletir, dando-lhe uma forma adequada, segundo o ponto de vista autoral. Esse processo desemboca no que Candido chama redução estrutural:

O processo por cujo intermédio a realidade do mundo e do ser se torna, na narrativa ficcional, componente de uma estrutura literária, permitindo que esta seja estudada em si mesma (CANDIDO, 1993, p.9).

Ao desenvolver esse conceito, Candido enfatiza a necessidade de compreensão da obra literária como intrinsecamente imbricada com a história, não sendo preciso buscar os fatos históricos fora do texto literário, como algo que apareceria apenas a partir do crítico. Ao contrário, esse traços estão no texto precisando apenas ser mostradas pela análise, a partir da própria representação literária.

É nesse sentido que a condição de autor de discurso, inclusive o literário, está diretamente proporcional ao domínio de um conjunto formado pelo conhecimento do código da área, da lógica da objetividade e pela possibilidade - dada pela objetividade - de intervenção na realidade, sendo objetivo da crítica, e do ensino de literatura, iluminar a reflexão do escritor e possibilitar a compreensão da realidade.

\section{Um lugar de reflexão}

A reflexão que estamos realizando passa necessariamente pela relação entre arte e história. Desse lugar teórico de interpretação da representação literária, a relação entre Arte e História deve ser entendida a partir da concepção que estabelece um entrecruzamento de coisas distintas e indissociáveis que possuem objetos e formas de expressar diferentes.

Seguindo essa abordagem, afirma-se que toda obra de arte pode ser estudada no seu imbricamento com a história, pois a 
verdadeira arte é um fazer história na medida em que é um refletir do ser social sobre sua própria existência. Não há história porque o sujeito do discurso resolveu contar alguns fatos, mas porque ele reflete sobre o seu tempo e as possibilidades de ultrapassá-lo.

Desse lugar teórico pode-se também afirmar que toda a objetivação artística possui um ponto de vista autoral, isto é, há um posicionamento do autor sobre a realidade refletida na obra, a marca de sua intencionalidade, ao escolher aquele conjunto de códigos e não outro para refletir na sua obra:

A eleição de um grupo contextual de objetos, sua conversão em mundo mediante a refiguração e a conformação mimética, é impossível sem uma tomada de posição com respeito àquele conteúdo e suas conexões, tomada de posição que constitui o ser-assim da parte do mundo eleita e sua elevação ao "mundo" estético (LUKÁCS, v.2, 1966, p.241).

Bakhtin trata também dessa questão através do conceito de intuito discursivo ${ }^{3}$, salientando que o sujeito do discurso possui um querer dizer, que influenciará nas escolhas discursivas que o autor realizará em seu texto (forma e conteúdo). Complementando essa questão, Pêcheux (1993/1998), através do entrecruzamento entre lingüística, materialismo histórico e psicanálise, argumentará que todo sujeito do discurso tem um lugar social que o condiciona (formação ideológica), tornando possível ao crítico perceber o lugar discursivo de onde o sujeito fala (formação discursiva). Na verdade, o querer dizer do sujeito, consciente estará sempre determinado pela ideologia, que é a representação ideal das relações sociais, determinadas pelas relações de trabalho. Afinando mais ainda essa conceituação, Pêcheux traz para o foco da análise o lugar do inconsciente, que desestabiliza o querer dizer, trazendo para os discursos os equívocos, os lapsos.

Reforçando essa argumentação, Bakhtin (1990), no estudo que faz da relação entre subjetividade e objetividade, afirma:

Um signo não existe apenas como parte de uma realidade; ele também reflete e refrata uma outra. Ele

3 Para o desenvolvimento do conceito ver Bakhtin (2000), principalmente das páginas 299 a 305. 
pode distorcer essa realidade, ser-lhe fiel, ou apreendê-la de um ponto de vista específico etc. Todo signo está sujeito aos critérios de avaliação ideológica (p.32).

É com essa concepção que estamos tratando das marcas de autoria, o que não requer, sob essa perspectiva, nenhuma incursão sobre as características psicológicas do autor como forma explicativa de sua composição autoral. Bakhtin, ao discutir a relação entre objetividade e consciência, sintetiza a questão da seguinte forma:

Tudo que dissemos acima conduz ao seguinte princípio metodológico: o estudo das ideologias não depende em nada da psicologia e não tem nenhuma necessidade dela. Como veremos, é antes o contrário que é verdadeiro: a psicologia objetiva deve se apoiar no estudo das ideologias (BAKHTIN,1990, p.36).

A ação da subjetividade artística, embora expresse a relação de um indivíduo com o mundo, não significa o posicionamento dessa subjetividade sobre as coisas da práxis imediata, pois, sendo a arte antropomórfica por natureza e função, encontra-se no âmbito das ideologias secundárias, que têm por objetivo o comportamento dos outros homens, isto é, provocar uma mudança para uma nova posiçāo ideológica (VAISMAN, 1989, p.415).

A afirmação de Vaisman remete à questão da intencionalidade da ação de todo reflexo estético. Embora expressão ideológica, a arte não tem pretensão nem compromisso de promover mudanças nas relações sociais que são contemporâneas do artista; o caráter ideológico da obra de arte é intrínseco a qualquer discurso artístico, por mais aparentemente abstrato ou fora da realidade que uma obra de arte possa parecer ou pretender que seja sua autoria.

Raymond Williams (1979, p.196) faz um paralelo entre 'o ponto de vista' estritamente estético, que diz respeito à estrutura narrativa, e o ponto de vista autoral, que, necessariamente, se relaciona com o primeiro, porém parte da imbricação do escritor com a realidade que está refletindo.

As descrições de grandes casas, de paisagens rurais, de cidades, ou de fábricas são exemplos evidentes dessas convenções variáveis, onde 'o ponto de vista' pode ser considerado como uma escolha 'estética', mas onde 
qualquer ponto de vista, inclusive aquele que inclui pessoas ou as transforma em paisagem, é social.

O ponto de vista terá a ver com a posição do autor em face da realidade e as suas possibilidades de conseguir a particularidade do real refletido. ${ }^{4} \mathrm{Na}$ realidade, está-se afirmando que existe sempre um projeto consciente de autoria, que traz implícita uma visão sobre a realidade refletida, podendo ser expresso de formas as mais diversificadas, que ultrapassam as classificações sobre o ponto de vista da teoria literária.

O ensino de literatura tem de necessariamente fazer a relação entre conteúdo e forma e sua indissociabilidade; pois a intenção do autor (do sujeito) é objetivada de uma determinada forma numa obra de arte, o que confere a essa atividade humana um movimento dialético específico. $\mathrm{O}$ momento pessoal tem importância constitutiva de toda objetividade e, contraditoriamente, é imprescindível à ultrapassagem de uma individualidade específica através de um deslocamento do cotidiano imediato:

O mundo da obra de arte, no qual se produz essa objetivação que assim põe à prova a subjetividade, é um reflexo da realidade objetiva, uma mímese que considera e reproduz do ponto de vista desse processo criador o mundo dado ao homem, tanto o produzido e elaborado por ele, como o que existe com independência em relação à humanidade (LUKÁCS, v.2, 1966, p.265).

O ensino de literatura, através da crítica de arte precisa encontrar o caminho escolhido pelo autor para expressar uma determinada realidade histórica; captando, através do uso de categorias intelectivas, a relação dialética explicitada pelo autor na obra, que necessariamente apresentará um ponto de vista de um sujeito particular e, ao mesmo tempo, expressará uma possibilidade da humanidade em relação à resolução das questões selecionadas pelo autor. Como afirma Candido (1993):

4 Possibilidade que tem a ver, também, com o domínio da técnica socialmente alcançada pelo período histórico da realização da obra e com a genialidade da autoria. 
O meu propósito é fazer uma crítica integradora, capaz de mostrar (não apenas enunciar teoricamente, como é hábito) de que maneira a narrativa se constitui a partir de materiais não literários, manipulados a fim de se tornarem aspectos de uma organização estética regida pelas suas próprias leis, não as da natureza, da sociedade ou do ser (p.9).

A vida em sua plenitude está contida na obra de arte, como afirma Bakhtin (1993); a forma estética tem o poder de transferir essa plenitude para um outro plano, que, no entanto, nunca pode significar, do ponto de vista da crítica, isolamento de partes dessa expressão artística, mas, ao contrário, necessita captar esse momento único em sua plenitude, seguindo o projeto do artista.

A análise de um texto literário necessita ultrapassar a materialidade discursiva para chegar à intencionalidade valorativa da obra (vale ressaltar que não se estão defendendo didatismos, nem apologias políticas, mas a intencionalidade de um sujeito que vive o mundo, reflete sobre ele e se posiciona de forma crítica). Descobrir o tipo de narrador, a relação entre as personagens, a trama, a forma do discurso etc. significa estar começando a análise crítica, que só poderá ter êxito se, após ou concomitante a essa fase, houver uma ultrapassagem para uma análise totalizante da obra, na medida em que toda expressão artística é realizada por uma subjetividade que carrega uma perspectiva sobre seu tempo e devenir histórico. ${ }^{5}$

Para o desvelamento do projeto da autoria, faz-se necessária a busca do caminho percorrido pela autoria, que não necessariamente coincide com a forma conclusa como se apresenta para o leitor.

A posição da autoria está presente na materialidade discursiva, mas sua explicitação só é possível a partir da compreensão da particularidade que foi congelada no reflexo artístico e que se consubstancia na criação de uma nova realidade, enquanto criação efetiva de um novo objeto (a obra de arte em si), e enquanto posicionamento sobre aquela realidade. Essa apreensão é apresentada

5 O tom enfático da afirmação tem por objetivo estimular a discussão com os que afirmam, tão enfaticamente quanto a posição aqui adotada, que a crítica literária que traz a marca do social não é análise literária, é análise sociológica. 
pela interdiscursividade, que traz o outro fazendo significar o mesmo. Na verdade, a voz social faz sentido através do dialogismo, que todo discurso (literário) estabelece com a história. A forma de exposição desenvolvida na ficção geralmente não é igual ao caminho percorrido pelo projeto autoral.

A gênese da arte consiste numa posição humana, produto de necessidades reais, que se vêm desenvolvendo, aprimorando desde sua origem e que, após o aparecimento, jamais deixou de acompanhar o caminhar do homem. Nas palavras de Klopstock, citado por Lukács (1967, p.205), tem-se o cerne da função da arte como resposta a uma necessidade essencialmente humana.

A essência da poesia está em que, com a ajuda da linguagem, mostra certo número de objetos que já conhecemos, ou cuja existência supúnhamos, mas por um lado que ocupa em tão alto grau as mais altas energias da alma, que, a uma obra sobre a outra, põe em movimento a alma inteira.

181)

Ou, nas palavras do poeta Manoel de Barros (1990, p.179-

Todas as coisas cujos valores podem ser disputados

no cuspe a distância servem para poesia.

$\mathrm{O}$ homem que possui um pente

e uma árvore

serve para poesia.

(...)

Pessoas desimportantes

dão pra poesia

qualquer pessoa ou escada

(...)

As coisas sem importância são bens de poesia.

Pois é assim que um chevrolê gosmento chega ao poema, e as andorinhas junto.

O estético se esforça por despertar uma totalidade humana a partir do mundo sensível; pela mímese, capta uma ampla e ordenada riqueza da realidade. A arte cria um mundo adequado ao homem e à humanidade. Vem responder à necessidade do homem de viver ao 
mesmo tempo o mundo real e objetivo e de adequá-lo a exigências do serhomem do homem. Por esse motivo, a arte é consciente/inconsciente em todos os momentos.

A mímese tem de se esforçar por captar todo o objeto em conexão com a subjetividade humana e, ao mesmo tempo, captar a forma como esse todo se manifesta na imediaticidade, isto é, um reflexo da realidade (objetivo) que seja capaz de se impor às impressões e vivências da cotidianidade e, simultaneamente, estar impregnado de subjetividade como elemento insuperável de seu serassim.

Uma proposta de análise

Faremos, a partir de agora, uma reflexão crítica sobre o poema de Otávio Cabral, Manhã.

\section{Manhã}

Para Sidney Wanderley

Não adianta insistir

Se a torneira está fechada

De que serve o poema ao homem

Se lhe sobra a palavra fome

E lhe falta a palavra vida?

Melhor seria fechar a torneira

(como fez o poeta)

Sepultando as metáforas

Transtornando as estrofes

Sufocando-as na garganta?

De que serve o poema ao homem

Quando o poema está rouco

E o homem já não ouve?

Ou melhor seria mesmo

Fechar a torneira

esperar sentado

O milagre do homem? 
Afinal

De que serve o poema ao homem

Quando the falta o milagre do peixe

E lhe sobra o destino em novena?

De que serve o poema ao homem

Se lhe falta o consumo da força

E lhe sobra o sonho ao delírio?

De que serve o poema ao homem

Se dele não extrai o último saldo

Nem digita a senha no supermercado?

De que serve o poema ao homem

Se não acessa a senha bancária

Nem reduz a parte do Imposto de Renda?

De que serve (enfim) o poema ao homem

Se dele não se serve o homem?

Quando muito quando nada

(Como o galo de Cabral

quando tecendo a manhã

que anuncia a outro galo

que o repassa a um outro

e a outro é repassado

para que outro o retome

e assim torne a repassar)

Para lembrar a esse homem

Como se inventa a manhã

Neste momento procederemos a uma análise dentro da perspectiva apresentada, para que sejam postas em prática as reflexões 
teóricas realizadas. Pretendemos mostrar, seguindo com Candido, como a reflexão sobre a realidade elaborada pelo reflexo estético ${ }^{6}$ tem a ver com o cotidiano, em determinado período histórico, embora possa ser, em um primeiro momento, percebida como algo que só acontece com os outros.

Para realizar tal intento, é necessário ressaltar a íntima relação entre a forma escolhida pela autoria para refletir determinado conteúdo. No caso em análise verificamos que o autor estabelece, através do uso do asterisco, uma divisão do poema que poderíamos chamar, para efeito de análise, introdução, desenvolvimento e conclusão. $\mathrm{Na}$ introdução, o poeta apresenta a temática de forma aparentemente conclusiva: Não adianta insistir/se a torneira está fechada. No que estamos denominando desenvolvimento, há uma desestabilização da possível afirmação da introdução, na medida em que as estrofes são finalizadas pelo ponto de interrogação; e, finalmente, na "conclusão" há a subversão da aparente afirmativa da introdução que passa, agora, no final do poema, a ser compreendida como uma interrogação que o poeta fazia para seu interlocutor direto, o poeta Sidney Wanderley, e para todos os leitores.

Percorremos o caminho da poesia a partir das marcas discursivas. A separação do poema nos autoriza a criar uma imagem de texto narrativo com uma seqüência lógica ${ }^{7}$, pois cria pausas que produzem um efeito de sentido de três momentos distintos, embora interligados pelo todo do desenho poemático.

A primeira imagem metafórica criada é a da intencionalidade de manter as torneiras fechadas; a pergunta que se segue se refere ao tipo de torneira que se quer lacrar, pois há uma afirmação de que não adianta insistir.

No entanto, logo em seguida, no segundo momento do poema, verificamos a que torneira o poeta se refere e as causas que fizeram a torneira ser fechada: não há lugar para a poesia neste mundo, pois ela se transforma em inutilidade quando confrontada com o cotidiano do ser humano.Como diz Manoel de Barros (1990), O poema é antes de

6 Sobre o conceito de reflexo estético ver Lukács,1967 e Magalhães,2001.

7 Evidentemente não se está afirmando seja esta a única leitura possível para as marcas de separação das partes do poema. 
tudo um inutensílio./ Hora de iniciar algum/ Convém se vestir roupa de trapo.

Como fazer poesia num mundo tão desumano, considerando que uma das funções sociais da arte está diretamente ligada à humanização do ser social? Como criar, num mundo de morte e sofrimento, que apenas considera o que tem utilidade prática.

Aparece aqui uma interdiscursividade com um dizer do senso comum já consagrado que considera as "literaturas" como diletantismo, como coisa de pessoas desocupadas, que não têm obrigação com a manutenção da vida. Na verdade, fazer poesia e ler poesia não fazem parte do cotidiano da maioria das pessoas que povoam a terra e que estão preocupadas com
A fome
O supermercado
O saldo bancário
O imposto de renda

O poeta conclui esse momento fazendo um jogo dialético entre poesia e homem:

De que serve (enfim) o poema ao homem

Se dele não se serve o homem?

É interessante ressaltar que, após várias interrogações que demonstram a inutilidade da poesia, o fechamento do que estamos chamando desenvolvimento da temática é realizado com a marca do parêntese contendo a palavra enfim, isto é, congregando todos os questionamentos feitos com tudo que pode ser acrescido com interdiscursos, que estão na memória discursiva sobre o lugar da poesia nas relações humanas. Perguntas que se ampliam sempre que a sociedade passa por períodos de grandes calamidades, como guerras, fome, violência. Sempre se pergunta: o que faz o poeta, para que serve a poesia? ${ }^{8}$

8 O reflexo artístico é uma práxis que, embora não prescinda das relações de produção, tem sua lógica diretamente restrita às relações entre os homens. Nesse sentido é que pode ser entendida como algo desnecessário para aqueles para quem as mínimas necessidades de sobrevivência não foram ainda atendidas. No entanto, ao ser realizado pelos homens, o 
É interessante ressaltar que, além dessa interdiscursividade do senso comum, há também um interdiscurso do próprio fazer poético que está sempre se questionando sobre a função da poesia no mundo. $\mathrm{Na}$ verdade, há uma metalinguagem, em que a poesia se questiona a si própria, tendo como base a relação contraditória que estabelece com um mundo dividido em classes sociais, em que a própria poesia precisa entrar na lógica do mercado, para ser também "consumida"por aqueles leitores que tiveram a oportunidade de manter contato com essa práxis humana e que tenham recursos para comprar livros.

Ferreira Gullar também debate esse assunto no poema $O$ açúcar, mostrando as contradições entre o lugar da poesia num mundo subdesenvolvido, onde as necessidades básicas do cidadão não são atendidas.

$$
\text { O Açúcar }
$$

O branco açúcar que adoçará meu café nesta manhã de Ipanema não foi produzido por mim nem surgiu dentro do açucareiro por milagre.

Vejo-o puro e afável ao paladar como beijo de moça, água na pele, flor que se dissolve na boca. Mas este açúcar não foi feito por mim.

Este açúcar veio da mercearia da esquina e tampouco o fez o Oliveira, dono da mercearia.

Este açúcar veio de uma usina de açúcar em Pernambuco ou no Estado do Rio e tampouco o fez o dono da usina.

reflexo estético cumpre a função social de autoconscientização do homem, enquanto parte do gênero humano. Evidentemente, em sociedade, onde as diferenças de classe dão a tônica da relação entre os seres sociais, um atividade que tende a refletir a alienação humana pelas relações de produção passa a ser encarada como algo supérfluo para uns e perigoso para outros. Para maior desenvolvimento do papel social da arte ver Marx (Ideologia Alemã, 1965 e Manuscritos filosóficos, 2001). 
Este açúcar era cana

e veio dos canaviais extensos

que não nascem por acaso

no regaço do vale.

Em lugares distantes, onde não há hospital

nem escola,

homens que não sabem ler e morrem de fome

aos vinte e sete anos

plantaram e colheram a cana

que viraria açúcar.

Em usinas escuras,

homens de vida amarga

e dura

produziram este açúcar

branco e puro

com que adoço meu café esta manhã em Ipanema.

Também nesse poema a função social da poesia está sendo questionada. Essa problemática foi exemplarmente discutida por Bastos(2002, p 82-3):

N'O Açúcar, de Ferreira Gullar, a voz lírica é a de um escritor personagem dilacerado pela consciência de que seu poema não só não pode escapar do universo da forma-mercadoria, como, mais do que isso, brota na verdade de seu solo. O alto refinamento artístico (o açúcar ou o doce de que fala o poema) é o último estágio de refinamento da produção capitalista. Assim colocado, nos termos da homologia entre o modo de produção econômica e o modo de produção literária, qual o sentido do fazer poético.

Enquanto o poeta (eu lírico) adoça seu café em condições humanas, há um quadro desumano de exploração do trabalho dentro do capitalismo: "Em usinas escuras,/homens de vida amarga/e dura/produziram este açúcar" que sustenta a possibilidade de refletir a realidade de forma poemática.

Há, na verdade, uma angústia não resolvida por parte do poeta, que expõe ao leitor a sua, mas também a contradição de uma sociedade dividida em classes sociais que torna possível o processo de 
desumanização refletido no poema. Ressalte-se que, como no poema de Otávio Cabral, também $O$ açúcar percorre o caminho que faz possível tal constatação e conclui, sobre a temática:

Este açúcar veio

da mercearia da esquina e tampouco o fez o Oliveira, dono da mercearia.

Este açúcar veio

de uma usina de açúcar em Pernambuco

ou no Estado do Rio

e tampouco o fez o dono da usina.

Este açúcar era cana

e veio dos canaviais extensos

que não nascem por acaso

no regaço do vale.

Em lugares distantes, onde não há hospital

nem escola,

homens que não sabem ler e morrem de fome

aos vinte e sete anos

plantaram e colheram a cana

que viraria açúcar.

Nessas duas estrofes a lógica da produção capitalista, com a exploração de classe, está exemplarmente relatada: aqueles que realizam o trabalho não são possuidores do fruto de seu trabalho; todo o processo de estranhamento ${ }^{9}$ do trabalho sob o modo de produção capitalista é desnudado, além de mostrar o caminho da produçãocirculação-consumo (a plantação da cana: Este açúcar era canal e veio dos canaviais extensos; a transformação em açúcar Este açúcar veio/de uma usina de açúcar em Pernambucolou no Estado do Rio; a comercialização: Este açúcar veio/da mercearia da esquina $e$ tampouco o fez o Oliveira,/dono da mercearia; e, finalmente, o consumo: com que adoço meu café esta manhã em Ipanema).

Concluída a trajetória do açúcar, percebe-se também o percurso do fazer poemático, que adoça a vida das pessoas, expresso pela repetição de alguns versos da primeira estrofe, para terminar o

9 Para o desenvolvimento do conceito de estranhamento ver Lukács, 1997 
poema, versos que, embora repetidos, possuem efeitos distintos, pois pertencentes a lugares discursivos diferentes.

O branco açúcar que adoçará meu café nesta manhã de Ipanema

não foi produzido por mim nem surgiu dentro do açucareiro por milagre.

e

Em usinas escuras, homens de vida amarga e dura produziram este açúcar branco e puro com que adoço meu café esta manhã em Ipanema.

Há uma imagem que parece congelar o ato de adoçar o café. Na primeira estrofe, o verbo no futuro indica que a ação ainda não foi concluída: adoçará. Para que a ação se consolide, foi necessária a constatação do caminho do açúcar. É interessante verificar que, também na primeira estrofe, o poema não está concluído. Percebe-se que as estrofes seguintes trazem imagens que se referem diretamente ao açúcar, mas que só são possíveis através de uma metaforização do gosto do açúcar com outras coisas, que o fazer poemático é capaz de transformar em algo igualmente doce. São estrofes de um lirismo grande, totalmente diferente do que será tratado em seguida:

Vejo-o puro e afável ao paladar

como beijo de moça, água

na pele, flor

que se dissolve na boca. Mas este açúcar

não foi feito por mim.

O preciosismo do fazer poético pode ser ressaltado no emprego do enjambement $t^{10}$, que traz imagens que levam o leitor a uma sensação de bem-estar. Até que, no último verso, a voz lírica diz que poesia pode fazer, mas açúcar não.

10 Recurso poético de concluir a imagem iniciada num verso somente no verso seguinte. Para maior aprofundamento ver Pound, p. 89-90. 
Na primeira estrofe há uma constatação (o branco açúcar que adoçará meu café (...) não foi produzido por mim) que cria uma imagem congelada, como se, ao sentar à mesa o poeta, começasse a refletir, sem ainda utilizar o açúcar. Após percorrer o caminho das relações sociais que possibilitam que o açúcar adoce seu café, desvelando o fetiche que a alienação capitalista produz ao silenciar como as coisas são produzidas, o poeta pode agora adoçar seu café, pois, com sua poesia, não resolveu a contradição básica do capital que tudo transforma em relações de troca, inclusive a poesia (produzida pelo poeta), mas possibilitou ao leitor a compreensão da lógica perversa do sistema de classe na sociedade contemporânea. E aí a voz lírica consuma o ato suspenso, utilizando o verbo no presente, e fecha o círculo (homens de vida amargal e dural produziram este açúcar/ branco e puro/com que adoço meu café da manhã em Ipanema). Percebe-se que, com o uso de imagens que se contradizem, o conflito de classe se desnuda: usinas escuras,vidas amargas, duras / açúcar doce, branco e puro.

Fizemos todo esse caminho com a poesia de Gullar para mostrar que as preocupações da voz lírica do poema Manhã encontram lugar no fazer poético. Voltemos então ao poema de Otávio Cabral. Nele, como vimos, também há sempre uma contraposição que na segunda estrofe relaciona fome e vida, plenitude de uma, falta da outra, mostrando a troca de lugares que as sociedades de classe produzem, pois o que deveria sobrar era a vida, e a fome deveria estar ausente do cotidiano dos seres humanos. ${ }^{11}$ Nesse mundo, o fazer poemático não encontra lugar. Por isso deve-se fechar a torneira

(como fez o poeta)

Sepultando as metáforas

Transtornando as estrofes

Sufocando-as na garganta?

11 No século XIX, os economistas liberais afirmavam ser impossível a igualdade social entre os homens, pois os bens produzidos não eram suficientes para todos; logo, sempre haveria grupos que ficariam em escassez. Hoje essa teoria foi desmascarada pela própria realidade, embora Marx já tivesse alertado que o problema não era de falta de produção, mas do tipo de relações de produção. O mundo hoje produz alimentos que dariam para alimentar todos os seres humanos, com as calorias necessárias ao organismo humano nas diferentes idades. 
Percebe-se que o poema se volta para o seu próprio fazer, falando das metáforas, linguagem própria dos poemas, das estrofes, forma estrutural da poesia. É um voltar-se sobre si próprio, um mergulho no interior do fazer poético, duvidando da sua função, do seu papel no mundo dos homens.

Depois de todos esses questionamentos, o que conclui o poema de Otávio Cabral? Na última estrofe, temos um diálogo direto com o poema de João Cabral de Melo Neto( 1994), Tecendo a manhã;

Um galo sozinho não tece uma manhã:

Ele precisará sempre de outros galos.

De um que apanhe esse grito que ele

E o lance a outro; de um outro galo

Que apanhe o grito que um galo antes

E o lance a outro; e de outros galos

Que com muitos outros galos se cruzem

Os fios de sol de seus gritos galo,

Para que a manhã, desde uma teia tênue, se vá tecendo, entre todos os galos.

A voz lírica chama o outro poeta, que não está discutindo o lugar da poesia, mas está construindo uma imagem da necessidade de muitas vozes para que se tenha a possibilidade de transformação de uma única voz em acontecimento - a manhã só se dá pela corrente formada pelos diversos galos que cantam. Da mesma forma, a poesia só será possível em momentos de muita fome e pouca vida se, em vez de fecharmos a torneira, fizermos o movimento contrário, isto é, fizermos jorrar todas as torneiras, encher o mundo de poesia para que todos possam se sentir humanos, mesmo em momentos tão desumanizados.

Serve o poema ao homem

Quando muito quando nada

(Como o galo de Cabral quando tecendo a manhã que anuncia a outro galo que o repassa a um outro e a outro é repassado para que outro o retome e assim torne a repassar) 


\section{Para lembrar a esse homem}

\section{Como se inventa a manhã}

Em termos discursivos, estamos assinalando uma heterogeneidade mostrada ${ }^{12}$, isto é, o sujeito do discurso (a voz lírica) torna explícito o discurso do outro, ao se referir aos versos de João Cabral $^{13}$, buscando não a forma nem o ritmo poemático, que são distintos, mas o efeito de sentido que o poema transmite.

$\mathrm{Na}$ verdade, com esse recurso o poeta responde a todos os questionamentos, ao incluir o termo conclusivo (enfim) do penúltimo verso do que chamamos desenvolvimento do tema - De que serve (enfim) o poema ao homem -, que funciona como somatório de todos os questionamentos que fez e dos que podem ser feitos sobre a função social da arte, o lugar da poesia no mundo a que Goldman (1976) chamava degradado.

Para responder, o poema vai buscar a imagem produzida por João Cabral, que, através dos cantos dos galos, faz amanhecer, e a ressignifica, criando outra imagem, a da necessidade de produzir poesia, para que ela acione o mecanismo de humanização que os seres sociais possuem.

$\mathrm{Na}$ verdade, o poema cria uma idéia de irmandade, de comunhão, que permite ${ }^{14}$ a qualquer leitor se sentir parte do gênero humano. Há, na estrofe final, um encadeamento que cria um ritmo sugestivo de uma corrente em que só se é vencedor se houver um compartilhamento de todos, como numa competição de revezamento.

É importante ressaltar que essa mensagem traz implícita ${ }^{15}$ a idéia de forças diferentes que se complementam. Os galos não cantam com a mesma intensidade, os atletas não correm com a mesma

12 Para aprofundamento desse conceito ver Authier Revue (1998).

13 Embora com o mesmo sobrenome, os poetas não apresentam parentesco. Otávio Cabral é alagoano, e João Cabral é pernambucano.

14 O fato de permitir a cada um a identificação com a humanidade não garante que todos os leitores se sintam irmanados, pois as condições de classe são tão fortes que tendem a apagar essa função da arte. No entanto, a arte cria essa possibilidade.

15 Para desenvolvimento da categoria de implícitos ver Cavalcanti (2002) 
velocidade, mas, se não se mantiverem com o mesmo objetivo, não haverá manhã, como não haverá vitória.

É nesse sentido que as torneiras têm de ser abertas. Todas. Aquelas que podem jorrar grandes quantidades e aquelas que apenas podem pingar, pois a função da arte só se completará, trazendo para a humanidade a noção de seu próprio gênero, se todas as formas artísticas se fizerem presentes em todas as épocas, mesmo naquelas em que tudo parece adverso para sua expressividade.

\section{Conclusão}

A relação entre história e literatura foi discutida, enfatizandose a necessidade desse entrelaçamento para o ensino da literatura, pois possibilita ao aluno perceber-se enquanto membro do gênero humano na reflexão feita pelo escritor, ao mesmo tempo que permite a imbricação entre a narrativa, o tempo e o espaço social, isto é, a narrativa e a sociabilidade que lhe serve de suporte, possibilitando, como diz Candido(1993), recriar a realidade a partir dela própria e dos códigos estéticos.

Outro aspecto debatido, que tem vinculação direta com o bom desempenho da disciplina literatura, foi a importância que assume o desvelamento do projeto autoral, do intuito discursivo do escritor (BAKHTIN, 2000), que possibilita, como nos diz Williams (1979), perceber o ponto de vista autoral.

Finalmente, enfatizou-se a necessidade do estudo do conteúdo e da forma (LUKÁCS, 1967) como uma relação que significa, que faz sentido, o que submete as características dos estilos de época ao reflexo estético.

Trabalhando esses conceitos, realizou-se uma análise dos poemas Manhã, de Otávio Cabral e $O$ açúcar, de Ferreira Gullar, ao se mostrar que um momento histórico foi refletido literariamente apresentando como ponto nodal dessa particularidade as dificuldades do reflexo estético em momentos de pauperização da população e de repressão à individualidade, que tendem a aniquilar a relação singularidade/generidade. $O$ indivíduo perde a capacidade de se ver como gênero, fazendo parte da humanidade, passando a sobreviver no emaranhado de seu cotidiano. 
Esse é o alerta fundamental de Otávio Cabral no poema, que registra o ponto de vista sobre uma particularidade histórica e artisticamente antecipa o futuro das sociedades que permitem/inibem a expressão artística. O fechamento das torneiras é uma possibilidade que precisa ser evitada, sob pena de a humanidade substituir a expressão artística por formas mistificadas de reflexão da realidade que afastam os seres sociais da procura de soluções para seus problemas.

Tratando a expressão literária dessa forma, estaremos fazendo com que ela ganhe vida através dos indivíduos (leitores), iluminando as formas da realidade, do mesmo modo que o poeta "inventa" um mundo em que não haja necessidade de questionamentos que contraponham poesia e fome, onde homens e mulheres, os mais diferentes possíveis, possam juntos, sempre juntos, reinventar o mundo a partir de suas próprias contradições, como Otávio Cabral reinventou a manhã de João Cabral.

\section{Referências}

AUTHIER-REVUZ, Jacqueline. Palavras incertas: as nãocoincidências do dizer. Campinas: Ed. Unicamp,1998.

ARANTES, Paulo Eduardo. Sentimento da dialética na experiência intelectual brasileira: dialética e dualidade segundo Antonio Candido e Roberto Schwarz. Rio de Janeiro: Paz e Terra, 1992.

BAKHTIN, Mikhail. Estética da criação verbal. Tradução de Maria Ermantina Galvão Gomes. São Paulo: Martins Fontes, 1992.

BAKHTIN, Mikhail. Marxismo e filosofia da linguagem. Tradução de Michel Lahud e Yara Frateschi Vieira. São Paulo: Hucitec, 1990.

BAKHTIN, Mikhail Estética da criação verbal. São Paulo: Martins Fontes,2000.

BARROS, Manoel de. Gramática expositiva do chão (Poesia quase toda). Rio de Janeiro, Civilização Brasileira, 1990.

BASTOS, Hermenegildo. Usinas escuras x Locus amoenus (A estética da mercadoria em $O$ açúcar, de Ferreira Gullar). Revista Leitura n.24 . Maceió: Edufal, 2002. 
BORGES, Jorge Luis. Esse ofício do verso. São Paulo: Companhia das Letras, 2000.

CABRAL, Otávio et al. Artesanias da palavra. Maceió: Grafmarques, 2001.

CABRAL, Otávio. Concerto em dor maior para choro e orquestra. São Paulo: Escrituras,2000.

CANDIDO, Antonio. $O$ discurso e a cidade. São Paulo: Duas Cidades, 1993.

CANDIDO, Antonio. Literatura e sociedade. 8ed. São Paulo: T. A Queiroz, 000.

CANDIDO, Antonio. Na sala de aula: caderno de análise literária. 5. ed. São Paulo: Ática, 1995

CAVALCANTE, Maria do Socorro. A.O. Implícitos e silenciamentos. Revista Leitura n.23. Maceió: Edufal, 2002

GOLDMANN, Lucien. Dialética e cultura. Tradução de Luiz Fernando Cardoso, Carlos Nelson Coutinho e Giseh Vianna Konders. 2. ed. Rio de Janeiro: Paz e Terra, 1979.

GOLDMANN, Lucien Sociologia do romance. 3. ed. Tradução Álvaro Cabral. Rio de Janeiro: Paz e Terra, 1976.

JAMESON, Fredric. Pós-Modernismo - A lógica cultural do capitalismo tardio. Tradução de Maria Elisa Cevasco. São Paulo: Ática, 1996.

JAMESON, Fredric. Os marxistas e a arte. Tradução de Iumna Maria Simon (Coord.). Rio de Janeiro: Civilização Brasileira, 1967.

LUKÁCS, Georg. Estética: la peculiaridad de lo estético (trad. esp.). Barcelona, México DF, Grijalbo, 1966/67.

LUKÁCS, Georg. Introdução a uma estética marxista (trad. bras.). Rio de Janeiro, Civilização Brasileira, 1978.

LUKÁCS, Georg. Ontologia do ser social: os princípios ontológicos fundamentais em Marx (trad. bras.). São Paulo, Ciências Humanas, 1979.

LUKÁCS, Georg. Marxismo e teoria da literatura. Rio de Janeiro: Civilização Brasileira, 1968. 
LUKÁCS, Georg. O trabalho. Tradução de Ivo Tonet. Maceió: 1997, mimeo.

MAGALHÃES, Belmira Vidas secas: os desejos de sinha Vitória. Curitiba: HDLivros,2001.

MAGALHÃES, Belmira. O sujeito do discurso: um diálogo possível e necessário. Revista Linguagem em discurso. Vol 3, Subjetividade (Org). Ingo Voese. Tubarão: ED UNISUL,2004.

MARX, Karl. A ideologia alemã. Rio de Janeiro: Zahar,1965.

MARX, Karl. Manuscritos econômicos e filosóficos. São Paulo: Martin Claret, 2001.

MELO NETO, João Cabral. Obra Completa. Rio de Janeiro: Nova Aguilar,1994.

ORLANDI, Eni Pulcinelli. Discurso e leitura. São Paulo: Cortez; Campinas: Editora da Unicamp, 1988.

ORLANDI, Eni Pulcinelli. Discuso e texto: formulação e circulação de sentidos. Campinas: Pontes, 2001.

PÊCHEUX, Michel. Semântica e discurso, uma crítica a afirmação do óbvio. Campinas: Editora da Unicamp, 1988

PÊCHEUX, Michel. Estrutura ou acontecimento. Tradução de Eni Orlandi. 3 ed. Campinas: Pontes, 2002.

POUND, Ezra. ABC da literatura. São Paulo: Cultrix, 1990.

WILLIMAS, Raymond. Marxismo e literatura. Tradução de Waltensir Dutra. Rio de Janeiro: Zahar, 1979. 